\title{
Sintering of Potassium Doped Hydroxy-Fluorapatite Bioceramics
}

\author{
Jihen Ben Slimen ${ }^{1}$, Mustapha Hidouri ${ }^{1}\left(\mathbb{D}\right.$, Marwa Ghouma $^{1}$, Ezzedine Ben Salem ${ }^{2}$ and Sergey V. Dorozhkin ${ }^{3, *}$ (D) \\ 1 Unit of Electrochemistry, Materials and Environment, Faculty of Sciences, Gabes University, \\ Erriadh City 6072, Tunisia; jihenbenslimen02@gmail.com (J.B.S.); mustapha.hidouri@isstgb.rnu.tn (M.H.); \\ marwa.ghouma12@gmail.com (M.G.) \\ 2 Unit of Materials and Organic Synthesis, Preparatory Institute of Engineering Studies, University of Monastir, \\ Monastir 5019, Tunisia; ezzedine.bensalem@ipeim.rnu.tn \\ 3 Kudrinskaja sq. 1-155, 123242 Moscow, Russia \\ * Correspondence: sedorozhkin@yandex.ru
}

Citation: Slimen, J.B.; Hidouri, M.; Ghouma, M.; Salem, E.B.; Dorozhkin, S.V. Sintering of Potassium Doped Hydroxy-Fluorapatite Bioceramics. Coatings 2021, 11, 858. https:// doi.org/10.3390/coatings11070858

Academic Editor: Devis Bellucci

Received: 12 June 2021

Accepted: 10 July 2021

Published: 17 July 2021

Publisher's Note: MDPI stays neutral with regard to jurisdictional claims in published maps and institutional affiliations.

Copyright: (c) 2021 by the authors. Licensee MDPI, Basel, Switzerland. This article is an open access article distributed under the terms and conditions of the Creative Commons Attribution (CC BY) license (https:// creativecommons.org/licenses/by/ $4.0 /)$.

\begin{abstract}
The present study describes the influence of potassium and hydroxyl substitutions on the structural, thermal and mechanical properties of fluorapatite bioceramics. A set of nonstoichiometric ion-substituted compounds, with a chemical formula of $\mathrm{Ca}_{10-x} \mathrm{~K}_{x}\left(\mathrm{PO}_{4}\right)_{6} \mathrm{~F}_{(2-2 x)}(\mathrm{OH})_{x}$ with $0 \leq x \leq 1$ synthesized by the wet precipitation method, were found to be single-phase apatites crystallizing in the hexagonal $\mathrm{P}_{3} / \mathrm{m}$ space group. The structural parameters, as well as the crystallite sizes, increased accordingly to the amount of added dopant-ions. The thermal behavior of these compounds, studied within the temperature range $500-1200{ }^{\circ} \mathrm{C}$, indicated a partial decomposition of the apatitic phase and its transformation to tricalcium phosphate $\beta-\mathrm{Ca}_{3}\left(\mathrm{PO}_{4}\right)_{2}$ at temperatures exceeding $750{ }^{\circ} \mathrm{C}$. A relative density of the sintered samples achieved the highest value with $x=0.25$ and reached about $95 \%$ after sintering at $1050{ }^{\circ} \mathrm{C}$ for $1 \mathrm{~h}$. The microstructures of the sintered samples were of a trans-granular aspect and experienced an increase in the radius of their pores as $\mathrm{x}$ increased. The prepared bioceramic materials were mechanically characterized by means of Young's modulus, flexural strength and fracture toughness measurements. The overall trend of these parameters evolved comparably to the relative density, and the maximum values obtained for $x=0.25$ were measured to be $96 \mathrm{MPa}, 47 \mathrm{MPa}$ and $1.14 \mathrm{MPa} \cdot \mathrm{m}^{1 / 2}$, respectively.
\end{abstract}

Keywords: ion-substitution; hydroxyfluorapatite; potassium; sintering; mechanical characterization

\section{Introduction}

Following the increasing prevalence of bone diseases, such as bone erosion, and the unceasing incidence of trauma accidents, both of which can damage the human skeletal system, there is an exhaustive demand for implantable biomaterials to replace organs that have failed. These biomaterials must comply with explicit specifications, such as nontoxicity, biocompatibility, bioactivity, osteoconductivity, etc. It is worth remembering that the bones and teeth of mammals are composites which consist of a mineral phase, where they are composed of calcium phosphates with an apatitic structure, and a bioorganic collagen-dominated phase [1-5]. Thereby, for a long time, synthetic calcium phosphates have been materials of interest for biomedical applications, and their properties are being continually improved to extend their applications as implantable biomaterials [6-11]. Among them, hydroxyapatite $\left(\mathrm{Ca}_{10}\left(\mathrm{PO}_{4}\right)_{6}(\mathrm{OH})_{2}\right.$, OHAp) has both a composition and a structure that are similar, but not fully identical, to the biologically formed apatites of calcified tissues. Moreover, if implanted, this material has an excellent bioactivity and allows bone growth by forming chemical bonds with living skeletal tissues [12] That is why a synthetic OHAp is considered as the most popular biomaterial used in orthopedical and dental surgery [13-16]. Fluorapatite $\left(\mathrm{Ca}_{10}\left(\mathrm{PO}_{4}\right)_{6} \mathrm{~F}_{2}, \mathrm{FAp}\right)$, a less soluble F-containing isotype of OHAp, also has rather similar properties to the mineral part of bones and teeth. Therefore, FAp is also considered as a biomedical material that plays a key role in preventing dental caries, increasing resistance to acid dissolution and decreasing 
mineral solubility [17-19]. In addition, due to their specific structure, all apatitic materials appear to allow various cationic and anionic substitutions that are used with the aim of achieving a composition resembling bone tissue. Thereby, partial substitutions of fluorides for hydroxides in FAp give rise to the formation of homogenous hydroxyfluorapatite (OH-FAp) bioceramics. It has been proven that OH-FAp minerals occur particularly in dental enamel [20]. In consequence, OH-FAp might be used in orthopedic and dental surgery as a surface coating for prothesis and dental implants. It should be noted that the fluorides present in the OH-FAp allow acid resistance and decrease solubility, both of which are indispensable for the teeth [21]. Moreover, many authors have suggested that OH-FAp has a better thermal and chemical stability compared to HAp [22,23].

Regarding ionic substitutions in apatites, potassium, as a minor constituent $(0.03-0.07 \mathrm{wt} \%)$, was found to play an important role in bone quality. It can increase bone strength by helping to protect against bone loss and can prevent osteoporosis [24-26]. Moreover, potassium is indispensable for bone nucleation and biomineralization processes [27]. The literature reports have revealed that doping by potassium has occurred without any significant effects on the structural stability of apatites, and that $\sim 20$ atom.\% were introduced into the apatite structure [28-30]. Meanwhile, lattice parameters slightly decreased when the level of substituted $\mathrm{K}^{+}$increased. Structural investigations showed that introduced $\mathrm{K}^{+}$in the FAp lattice was localized on $\mathrm{Ca}$ (I) sites, creating vacancies in $\mathrm{F}^{-}$and $/ \mathrm{or} \mathrm{OH}^{-}$sites to compensate for charge imbalances [31-33]. However, to date, there are no evident data on the mechanical characterizations of potassium substituted apatites. Therefore, in the present study, a series of $\mathrm{OH}$-Fap bioceramics, with variable amounts of potassium as a substitute for calcium, were studied and sintering properties and mechanical characterizations were investigated.

\section{Materials and Methods}

\subsection{Sample Preparation}

The Fap powders, both pure and $\mathrm{K}^{+}$and $\mathrm{OH}^{-}$substituted ones, with a general chemical formula of $\mathrm{Ca}_{10-x} \mathrm{~K}_{\mathrm{x}}\left(\mathrm{PO}_{4}\right)_{6} \mathrm{~F}_{(2-2 x)}(\mathrm{OH})_{x}$, with $x=0.25,0.5$, 0.75, or 1.0 were prepared by the classical wet precipitation method [23]. The starting reagents were solid $\mathrm{Ca}\left(\mathrm{NO}_{3}\right)_{2} \cdot 4 \mathrm{H}_{2} \mathrm{O}$ (Riedel-de Haën, $98 \%$ assay), $\mathrm{KNO}_{3}$ (Fluka, $98 \%$ assay), $\left(\mathrm{NH}_{4}\right)_{2} \mathrm{HPO}_{4}$ (Fluka, 98\% assay), $\mathrm{NH}_{4} \mathrm{~F}$ (Siegfried Handel, 97\% assay) and an aqueous solution of $\mathrm{NH}_{4} \mathrm{OH}$ (Panreac, 28\% assay).

The synthesis of the samples involved dissolving the reagents in deionized water, followed by adding the reactants to obtain the final product at the molar ratio $(\mathrm{K}+\mathrm{Ca}) / \mathrm{P}=1.66$. In brief, $750 \mathrm{~cm}^{3}$ of a solution containing dissolved calcium and potassium nitrates with a total concentration of $5 \times 10^{-3} \mathrm{~mol}$ for $\mathrm{Ca}+\mathrm{K}$ was drop-wisely added using a peristaltic pump to $750 \mathrm{~cm}^{3}$ of a boiling and vigorously stirred solution of $3 \times 10^{-3} \mathrm{~mol}$ dissolved ammonium phosphate as the source of $\mathrm{P}$ and the necessary amount of $\mathrm{NH}_{4} \mathrm{~F}$ as the source of $\mathrm{F}$. In all experiments, the amounts of $\left(\mathrm{NH}_{4}\right)_{2} \mathrm{HPO}_{4}$ were always kept constant and were equal to $3 \times 10^{-3} \mathrm{~mol}$, while the amounts of the other reagents depended on the numerical values of $x$. Namely, for $x=1,10 \mathrm{~mol}$. $\%$ of calcium nitrate were replaced by $\mathrm{KNO}_{3}$ (i.e., the solution contained $4.5 \times 10^{-3} \mathrm{~mol} \mathrm{Ca}\left(\mathrm{NO}_{3}\right)_{2}$ and $\left.0.5 \times 10^{-3} \mathrm{~mol} \mathrm{KNO}_{3}\right)$, with the subsequent decrease in the amount of $\mathrm{NH}_{4} \mathrm{~F}$. The $\mathrm{pH}$ of the reaction was adjusted to 9 and was kept constant by means of automatic ammonia addition. Once the whole amounts of the solutions were added, the suspension was kept maturated for $2 \mathrm{~h}$ under continuous stirring at $95^{\circ} \mathrm{C}$. Afterwards, it was hot filtered, and the precipitates were washed with distilled water and then dried in an oven at $70{ }^{\circ} \mathrm{C}$ for $12 \mathrm{~h}$ until a constant weight was obtained.

\subsection{Powder Characterization}

Phase identifications, lattice parameters and crystal size determinations were performed by X-ray diffraction (XRD) analysis (PRO PANALYTICALX'pert PRO, Faculty of Sciences, Bizerte, Tunisia) using $\mathrm{Cu} \mathrm{K} \alpha$ radiation at $30 \mathrm{kV}$ and $20 \mathrm{~mA}$. The XRD analyses were carried out over the $2 \theta$ range of $20^{\circ}$ to $60^{\circ}$ with a step size of $0.02^{\circ}$ per second and 
a counting time of $0.5 \mathrm{~s}$ per step. Crystallographic identifications of the studied samples were accomplished by a comparison with the standards compiled by the Joint Committee on Powder Diffraction and Standards (JCPDS cards \# 34-0011 and \# 09-0432 for FAp and OHAp, respectively).

The infrared spectra of the synthesized apatites were recorded by a Nicolet Magna-IR 550 spectrophotometer (Faculty of Sciences, Gabes, Tunisia) in the $4000-400 \mathrm{~cm}^{-1}$ spectral range. The measured data were collected in the attenuated total reflectance (ATR) mode. The ${ }^{31} \mathrm{P}$ nuclear magnetic resonance $\left({ }^{31} \mathrm{P}\right.$ NMR) measurements were performed on a Bruker $300 \mathrm{WB}$ spectrometer (ENI, Sfax, Tunisia) at a frequency of $121.49 \mathrm{MHz}$. The chemical analysis for calcium, potassium and phosphorus of the prepared samples was carried out by dissolving them in an excess of $0.1 \mathrm{~N}$ nitric acid, followed by using an ICP-OES Perkin Elmer, Optima 3000 DV model apparatus (CPG, Gabes, Tunisia), while the fluoride amounts were potentiometrically controlled with a PF4-L specific $\mathrm{F}^{-}$-selective electrode. In addition, differential and thermogravimetric analyses (DTA-TGA) were performed using a Setaram 92-16.18 apparatus (ENI, Gabes, Tunisia) with a heating rate of $10^{\circ} \mathrm{C} / \mathrm{min}$.

\subsection{Sintering and Mechanical Assays}

After being prepared, the dry powders of K-doped apatites were uniaxially isostatically cold compacted using a die of $30 \mathrm{~mm}$ in diameter and $3 \mathrm{~mm}$ thick under a pressure of $100 \mathrm{MPa}$. After that, they were pressurelessly sintered between 950 and $1250{ }^{\circ} \mathrm{C}$ with a step of $50{ }^{\circ} \mathrm{C}$ and a fixed dwelling of $1 \mathrm{~h}$. A programmable Carbolyte type furnace (EPEI, Monastir, Tunisia) rassured the sintering had $10{ }^{\circ} \mathrm{C} / \mathrm{min}$ heating and cooling rates. The densities of the sintered bodies were determined by Archimed's method. The morphology of the fracture surfaces was investigated using a scanning electron microscope (SEM, Philips XL 30, (ENI, Sfax, Tunisia) operated at $20 \mathrm{kV}$ with a tungsten filament. To perform the observations, the dry samples were gold spattered in a vacuum for $5 \mathrm{~min}$. Afterwards, the mechanical properties of the dense specimens were investigated by measurements of Young's modulus (E), which was determined by the pulse-echo method using a Grindo sonic system Lemmens (ENSI, Limoges, France). In addition, flexural strength was measured by a three-point-bending technique using a Wolpert 5TZZ 771 instrument. Finally, fracture toughness $\left(\mathrm{K}_{\mathrm{IC}}\right)$ was determined by means of the Vickers indentation technique durometer Zwick 3212 (ENI, Monastir, Tunisia). The $\mathrm{K}_{\mathrm{IC}}$ values were calculated using the equation derived from the Evans and Charles model and have been previously detailed [34,35]. All measurements were performed for 4 individual samples in a row and the average values were calculated.

\section{Results}

\subsection{Phase Analysis}

The XRD patterns of the synthesized powders given in Figure 1 revealed that all samples were of an apatitic structure. The patterns appeared to be comparable for all samples and coincided with the ICCD standard of FAp (JCPDS \# 34-0011), and no evidence of any crystalline phases other than apatite were detected. The peaks of the K-substituted $\mathrm{OH}-\mathrm{FAp}$ samples were sufficiently intense and did not differ from those of unsubstituted FAp. As expected, the incorporation of $\mathrm{K}^{+}$and $\mathrm{OH}^{-}$ions into the FAp structure was accompanied by a reduction in lattice parameters $a$ and $c$ compared to the unsubstituted FAp. The calculation results by the least squares method listed in Table 1 showed a particular decrease for $a$ parameter while $c$ parameter was slightly varied. The $a$ variation was governed by two antagonist effects: firstly, the substitution of $\mathrm{K}^{+}(0.138 \mathrm{~nm})$ for $\mathrm{Ca}^{2+}(0.100 \mathrm{~nm})$ induced an increase in the $a$ values; however, as it was reported in the literature, the substitution of a divalent cation by a monovalent one decreased the channel diameter of $a$ parameter and in consequence, $a$ markedly decreased $[28,29,31]$. Secondly, the bibliography on hydroxfluorapatites reported that $a$ parameter increased with a decreasing degree of fluoridation $[36,37]$. In present work, a contraction of the lattice parameters suggested was attributed to $\mathrm{K}^{+}$substitution. 


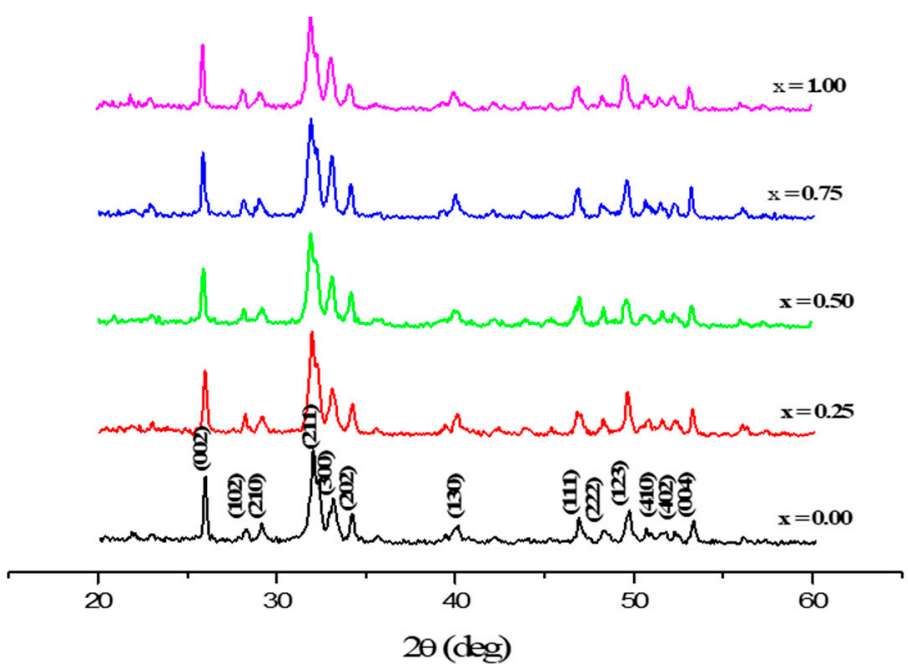

Figure 1. XRD patterns of the synthesized $\mathrm{Ca}_{10-x} \mathrm{~K}_{x}\left(\mathrm{PO}_{4}\right)_{6} \mathrm{~F}_{(2-2 x)}(\mathrm{OH})_{x}$ for $0 \leq x \leq 1$.

Table 1. Lattice parameters, unit cell volume and crystallite sizes for $\mathrm{Ca}_{10-x} \mathrm{~K}_{x}\left(\mathrm{PO}_{4}\right)_{6} \mathrm{~F}_{(2-2 x)}(\mathrm{OH})_{x}$ for $0 \leq x \leq 1$.

\begin{tabular}{ccccccc}
\hline $\mathbf{x}$ & $\mathbf{a}(\mathbf{p m})$ & $\mathbf{c}(\mathbf{p m})$ & $\mathbf{V ~} \mathbf{( 1 0}^{\mathbf{6}} \mathbf{p m}^{\mathbf{3}} \mathbf{)}$ & $\mathbf{D}_{\mathbf{3 0 0}}$ & $\mathbf{D}_{\mathbf{0 0 2}}$ & $\mathbf{D}_{\mathbf{0 2 2}}$ \\
\hline 0.00 & $934.3(1)$ & $685.4(1)$ & $517.0(1)$ & $462(2)$ & $437(2)$ & $423(4)$ \\
0.25 & $932.4(2)$ & $685.2(2)$ & $515.4(2)$ & $448(2)$ & $432(3)$ & $419(3)$ \\
0.50 & $931.8(1)$ & $685.7(1)$ & $514.69(3)$ & $434(3)$ & $442(2)$ & $408(2)$ \\
0.75 & $931.3(1)$ & $686.1(1)$ & $515.32(1)$ & $413(3)$ & $436(3)$ & $402(3)$ \\
1.00 & $930.7(2)$ & $686.3(2)$ & $514.81(2)$ & $407(4)$ & $448(4)$ & $393(3)$ \\
\hline
\end{tabular}

The crystallite sizes (value D) for all samples were calculated using the Debye-Sheerer equation from the XRD reflections (300), (002) and (022) [38]:

$$
D=\frac{K \lambda}{\beta_{1 / 2} \operatorname{Cos} \theta}
$$

where $K$ is equal to 0.9 for the apatite crystallites, $\lambda$ is the $\mathrm{X}$-ray monochromatic radiation wavelength, $\beta_{1 / 2}$ is the full width at half maximum of the chosen reflection and $\theta$ is the Bragg's diffraction angle. The numerical values given in Table 2 indicated that substitutions of $\mathrm{K}^{+}$and $\mathrm{OH}^{-}$in the FAp structure decreased the crystallite sizes when amounts of the doping-ions increased.

Table 2. Chemical analysis results in $\mathrm{mmol} / \mathrm{g}$ of $\mathrm{Ca}_{10-x} \mathrm{~K}_{x}\left(\mathrm{PO}_{4}\right)_{6} \mathrm{~F}_{(2-2 x)}(\mathrm{OH})_{x}$ for $0 \leq x \leq 1$.

\begin{tabular}{ccccccc}
\hline $\mathbf{x}$ & $\mathbf{C a}$ & $\mathbf{K}$ & $\mathbf{P}$ & $\mathbf{F}$ & $\begin{array}{c}\mathbf{C a} / \mathbf{P} \\
\text { Molar Ratio }\end{array}$ & $\begin{array}{c}(\mathbf{K}+\mathbf{C a} / \mathbf{P} \\
\text { Molar Ratio }\end{array}$ \\
\hline 0.00 & $9.89(2)$ & - & $5.94(3)$ & $1.97(2)$ & $1.67(3)$ & $1.66(3)$ \\
0.25 & $9.70(3)$ & $0.22(2)$ & $5.95(3)$ & $1.46(3)$ & $1.64(3)$ & $1.66(3)$ \\
0.5 & $9.42(3)$ & $0.45(3)$ & $5.94(3)$ & $0.95(2)$ & $1.59(3)$ & $1.66(3)$ \\
0.75 & $9.20(2)$ & $0.71(3)$ & $5.95(2)$ & $0.47(3)$ & $1.54(2)$ & $1.66(3)$ \\
1.00 & $8.95(2)$ & $0.95(3)$ & $5.94(3)$ & traces & $1.50(3)$ & $1.66(3)$ \\
\hline
\end{tabular}

Figure 2 illustrates the infrared spectra of the synthesized samples. The spectra revealed typical FAp absorption bands. Namely, the bands attributable to the $\mathrm{PO}_{4}{ }^{3-}$ group were detected as the following: the bands assigned at 960,1030 and $1100 \mathrm{~cm}^{-1}$ were characteristic of the $\mathrm{P}-\mathrm{O}$ stretching vibrations while those at 570 and $600 \mathrm{~cm}^{-1}$ were assigned to $\mathrm{O}-\mathrm{P}-\mathrm{O}$ bending. The additional bands assigned to impurities contained in the prepared powders were also present. Namely, an absorption band observed at the region $1380-1480 \mathrm{~cm}^{-1}$ was attributed to the traces of nitrates; their presence originated from the 
starting precursors and was completely removed by calcination at $500{ }^{\circ} \mathrm{C}$. The presence of nitrates was previously detected in ion-substituted apatites [35].

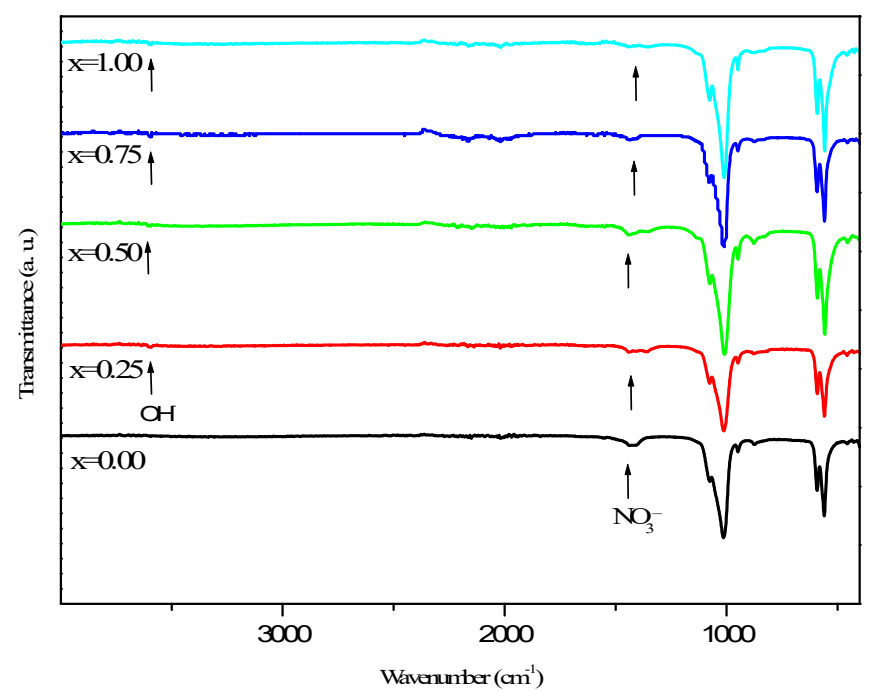

Figure 2. Infrared spectra of synthesized $\mathrm{Ca}_{10-x} \mathrm{~K}_{x}\left(\mathrm{PO}_{4}\right)_{6} \mathrm{~F}_{(2-2 x)}(\mathrm{OH})_{x}$ for $0 \leq x \leq 1$. Arrows indicate the traces of $\mathrm{OH}$ and nitrates.

As advanced by Šupová [39], a substitution of divalent $\mathrm{Ca}^{2+}$ by monovalent $\mathrm{K}^{+}$caused a charge imbalance, and the electroneutrality could be maintained by creating vacancies or by simultaneous anionic and cationic substitutions. As there a substitution of $\mathrm{F}^{-}$by $\mathrm{OH}^{-}$, we deduced that no vacancies within the $\mathrm{F}^{-}$site might be present. A very weak absorption band of $\mathrm{OH}^{-}$at $3495 \mathrm{~cm}^{-1}$ supported this. One needs to stress that this absorption band was observed solely for K-substituted samples.

The solid phase ${ }^{31} \mathrm{P}$ NMR spectra at magic angle spinning at $8 \mathrm{KHz}$ for $x=0.25$ and $x=0.75$ samples are shown in Figure 3. These spectra exhibited a single isotropic signal indicating the existence of a unique crystallographic site for phosphorus in K-doped OH-FAp environment. The chemical shift of both samples found around $3.8 \mathrm{ppm}$ was consistent with studies on substituted FAp [35,40].

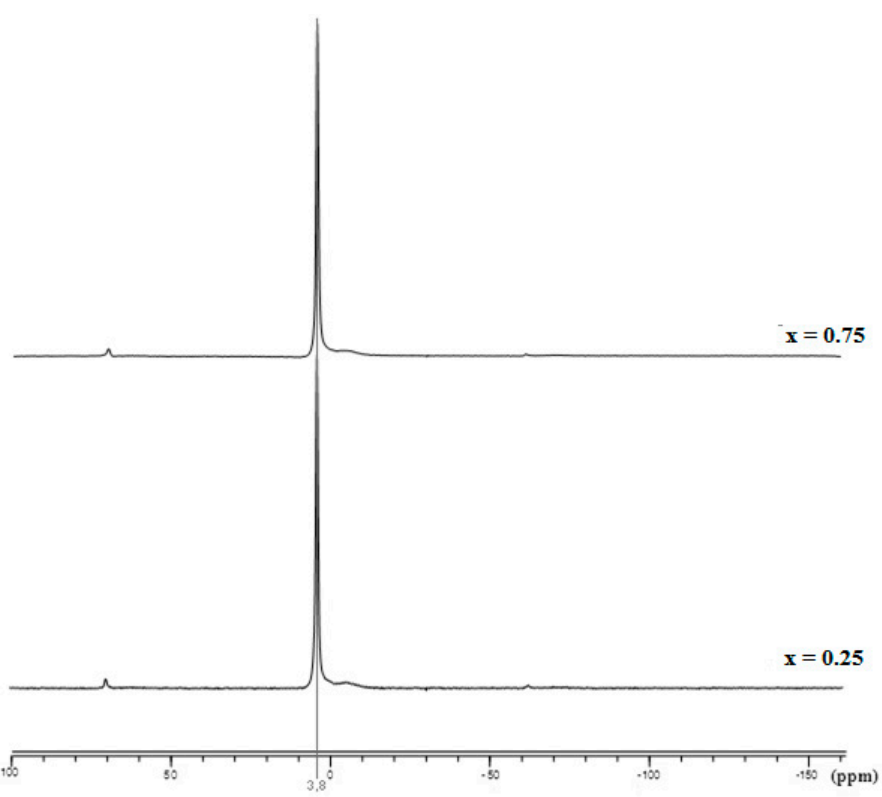

Figure 3. Infrared spectra of synthesized $\mathrm{Ca}_{10-x} \mathrm{~K}_{x}\left(\mathrm{PO}_{4}\right)_{6} \mathrm{~F}_{(2-2 x)}(\mathrm{OH})_{x}$ for $x=0.25$ and $x=0.75$. 
The quantitative results of chemical analyses for the elements contained in the samples are shown in Table 2. As seen in the K column, the amount of potassium in the samples was close to those introduced and given by $x$ values showing that all $\mathrm{K}^{+}$was incorporated in the synthesized samples. Namely, the $\mathrm{Ca} / \mathrm{P}$ molar ratios decreased as potassium amounts increased, indicating once again that calcium for potassium substitution had occurred. The $(\mathrm{Ca}+\mathrm{K}) / \mathrm{P}$ molar ratios were very close to 1.67 , the stoichiometric value known for the calcium apatite. On the other hand, the fluorine contents given in the $\mathrm{F}$ column were in accordance with the nominal compositions given by $2-2 x$ calculations. The overall results of chemical analyses indicate that potassium and hydroxyl substitutions in FAp bioceramics occurred.

\subsection{Thermal Behavior}

The differential thermal (DTA) and thermogravimetric (GTA) analyses curves plotted in Figure 4 showed that the transformations occurred during the heating of the sample $x=0.5$ from room temperature to $1000{ }^{\circ} \mathrm{C}$. The GTA plot showed a continuous weight loss with increasing temperature; namely, in the temperature range between 50 and $200{ }^{\circ} \mathrm{C}$, the samples were the subject of a weight loss of $\sim 4 \%$. This meets an endothermic phenomenon occurring around $92{ }^{\circ} \mathrm{C}$ due to the elimination of absorbed water. At the temperature range $210-340{ }^{\circ} \mathrm{C}$, a $5 \%$ weight loss coincides with an endothermic peak at around $230^{\circ} \mathrm{C}$ and corresponds to the decomposition of nitrates. Finally, the exothermic peak at around $750{ }^{\circ} \mathrm{C}$, accompanied by a weight loss of about $4 \%$, was attributed to a partial decomposition of apatites to tricalcium phosphate, as reported in many studies $[35,37]$. The presence of formed $\beta-\mathrm{Ca}_{3}\left(\mathrm{PO}_{4}\right)_{2}$ was confirmed by XRD spectra shown in Figure 5.

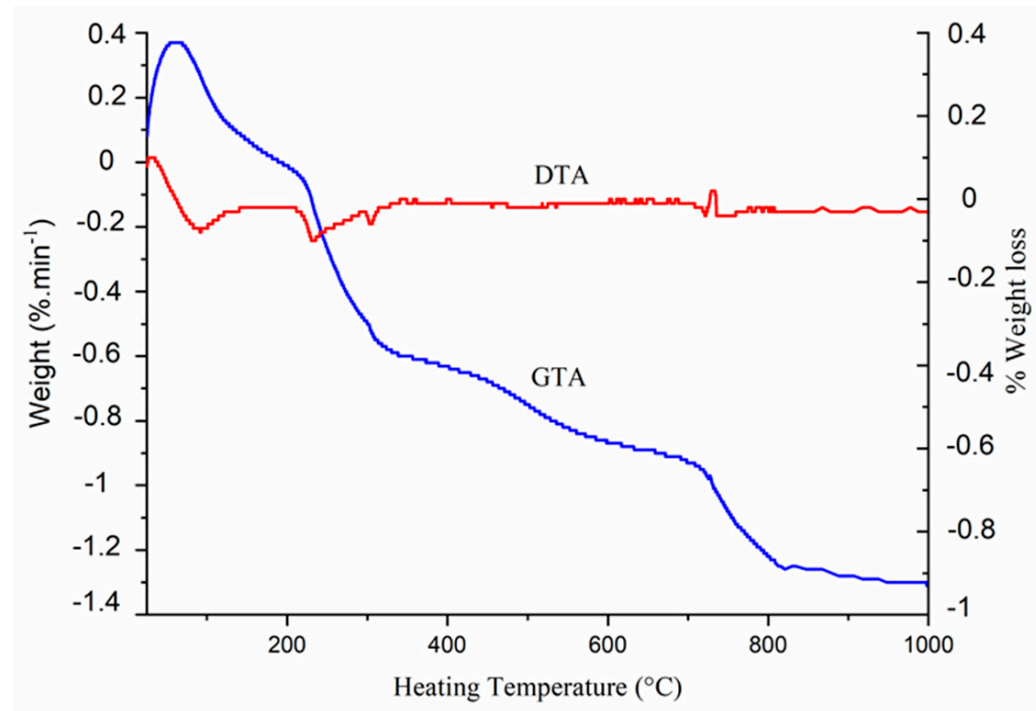

Figure 4. Differential thermal (left $Y$-axis) and thermogravimetric (right $Y$-axis) analyses of synthesized Ca9.5 $\mathrm{K}_{0.5}\left(\mathrm{PO}_{4}\right)_{6}(\mathrm{OH})_{0.5} \mathrm{~F}$ sample. 


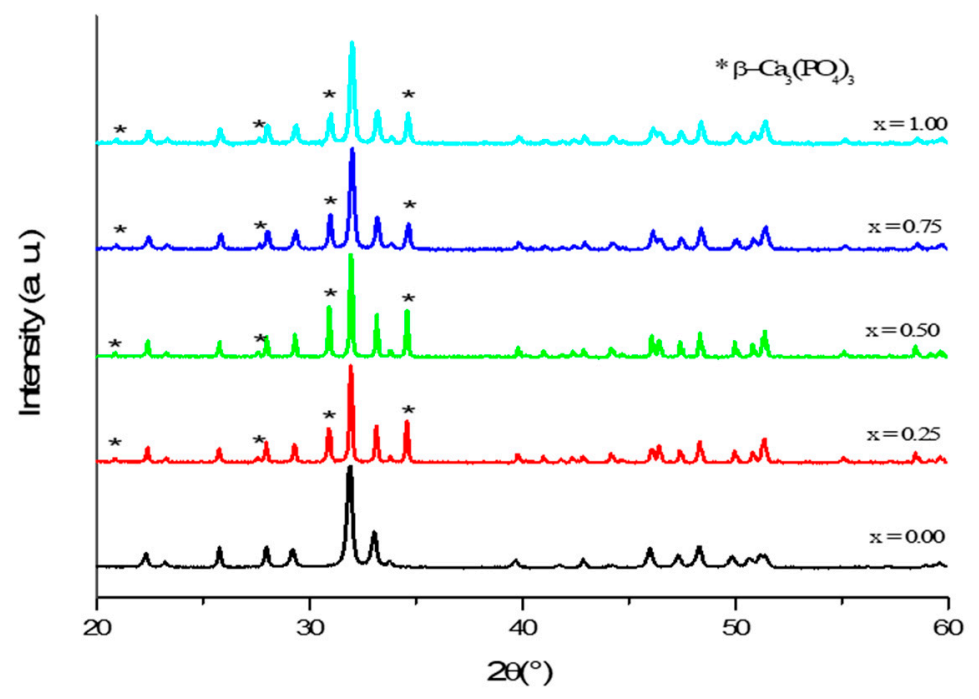

Figure 5. $\mathrm{XRD}$ spectra of $\mathrm{Ca}_{10-x} \mathrm{~K}_{x}\left(\mathrm{PO}_{4}\right)_{6} \mathrm{~F}_{(2-2 x)}(\mathrm{OH})_{x}$ for $0 \leq x \leq 1$, calcined at $1050{ }^{\circ} \mathrm{C}$.

\subsection{Sintering}

The impact of the sintering temperature on the relative densities of the sintered samples when $x$ rises is shown in Figure 6. All plots have roughly the same trend, suggesting that the sintering mechanism was the same. The densities did not exceed $\sim 92 \%$ at temperatures 900 and $1000{ }^{\circ} \mathrm{C}$, then markedly increased at $1050{ }^{\circ} \mathrm{C}$ to attain $\sim 96 \%$, after which they gradually decreased. We consider that $1050{ }^{\circ} \mathrm{C}$ and a holding time of $1 \mathrm{~h}$ are the optimal conditions for maximum densification. On the other side, the effect of $\mathrm{K}^{+}$and $\mathrm{OH}^{-}$doping levels on the densification of FAp samples sintered at various temperatures is shown in Figure 7. It was found that the obtained densities decreased as the doping levels increased. The highest density values were obtained for undoped FAp, whereas within substituted samples, the composition where $x=0.25$ exhibited the highest relative density values $(\sim 95 \%)$. A similar densification behavior was noted for the OH-FAp samples containing magnesium and silica as substituents $[37,41]$.

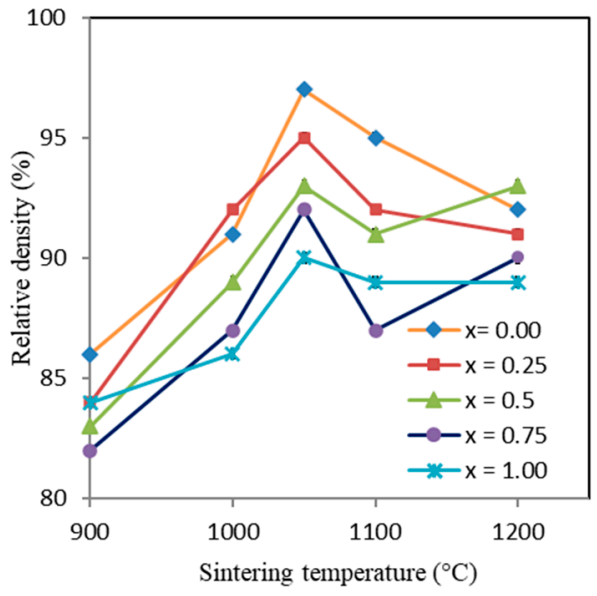

(a)

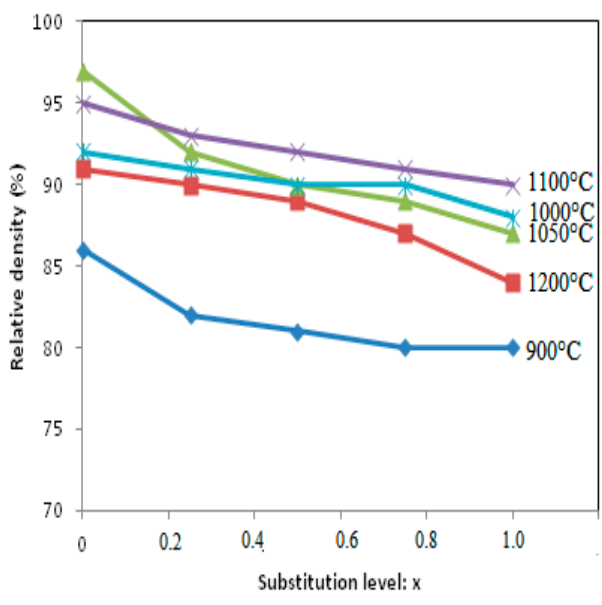

(b)

Figure 6. Relative density values (accuracy $\pm 1.5 \%$ ) of $\mathrm{Ca}_{10-x} \mathrm{~K}_{x}\left(\mathrm{PO}_{4}\right)_{6} \mathrm{~F}_{(2-2 x)}(\mathrm{OH})_{x}$ for $0 \leq x \leq 1$ versus. (a) Sintering temperature (b) Substitution level x. 

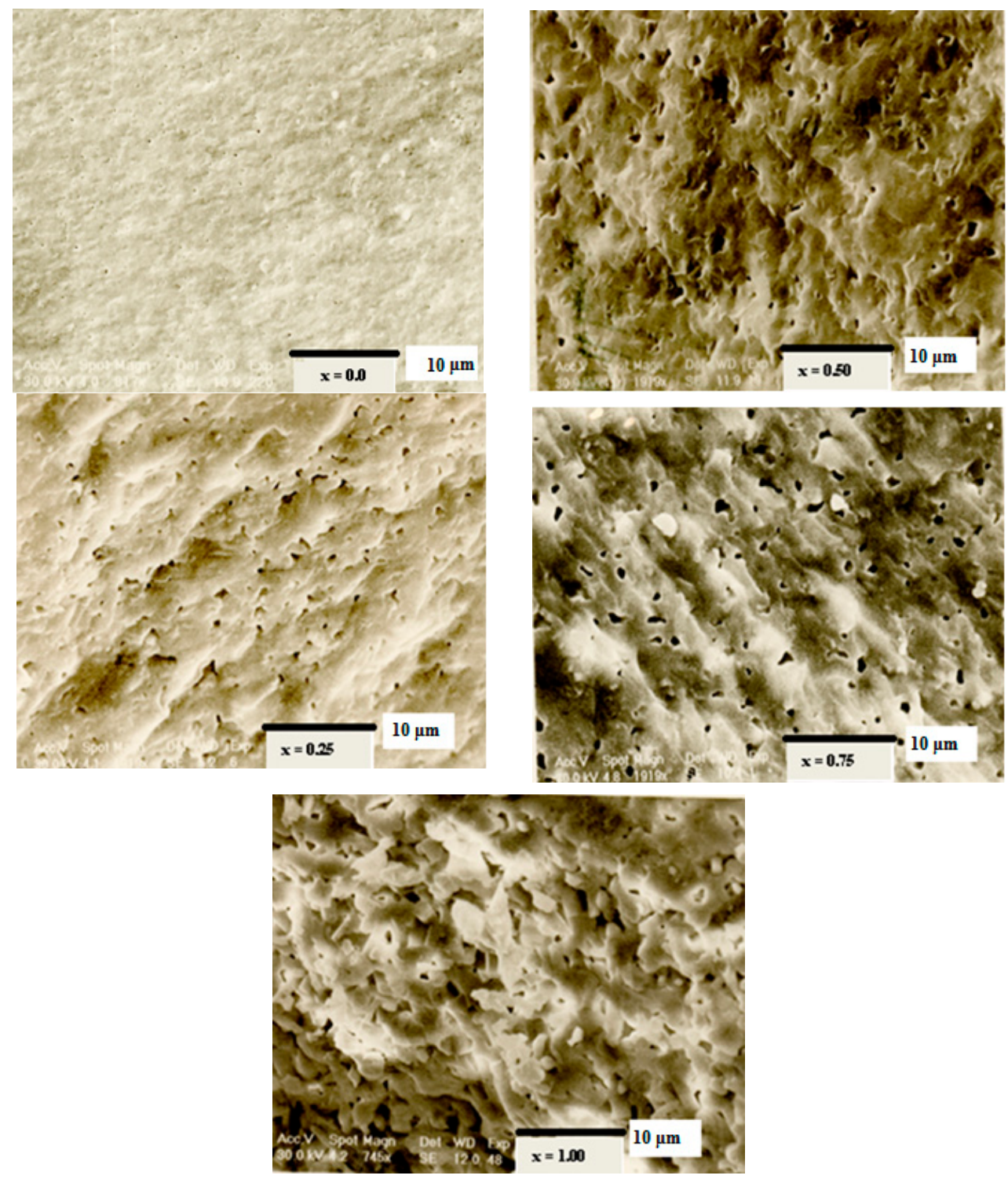

Figure 7. SEM micrographs of the fracture surfaces of the $\mathrm{Ca}_{10-x} \mathrm{~K}_{x}\left(\mathrm{PO}_{4}\right)_{6} \mathrm{~F}_{(2-2 x)}(\mathrm{OH})_{x}$ for $0 \leq x \leq 1$ samples sintered at $1050{ }^{\circ} \mathrm{C}$ for $1 \mathrm{~h}$.

The SEM micrographs of the sintered samples given in Figure 7 revealed that fracture modes were fully trans-granular. Few pores crossed the fracture surface of pure FAp and coincided with the obtained density ratios ( $96 \%)$. However, inter-granular porosity was observed with the K-substituted compacts. The occurrence of such porosities increased as $x$ rose.

\subsection{Mechanical Characterizations}

During mechanical characterizations of the studied K-OH-FAp samples, the numerical values of the Young's modulus $\mathrm{E}$ were found to be of a similar trend to that of densification. The values for unsubstituted FAp were slightly higher than those for Ksubstituted ones and a maximum of $102 \mathrm{MPa}$ was obtained at $1050{ }^{\circ} \mathrm{C}$, whereas as the doping with potassium and hydroxide level increased, the E values decreased (Figure 8). This decrease might relate to porosity increasing for the substituted samples. As previously indicated, $\mathrm{K}^{+}$and $\mathrm{OH}^{-}$substitutions increased the crystallite dimensions disproving the material densification. 


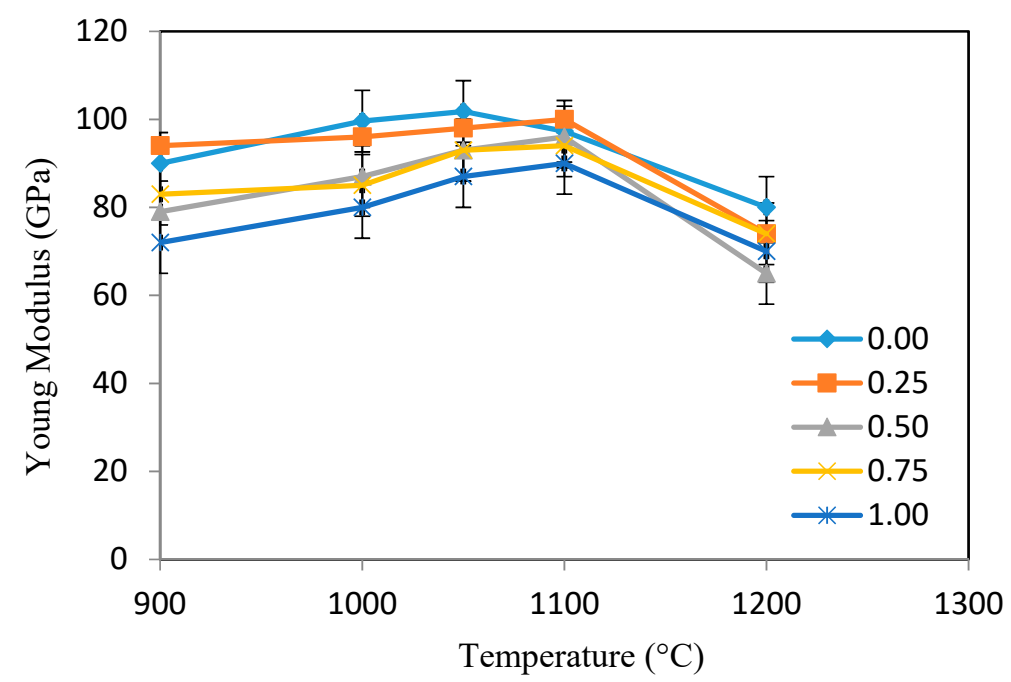

Figure 8. Numerical values of the Young's modulus for $\mathrm{Ca}_{10-x} \mathrm{~K}_{x}\left(\mathrm{PO}_{4}\right)_{6} \mathrm{~F}_{(2-2 x)}(\mathrm{OH})_{x}$ for $0 \leq x \leq 1$ sintered at various temperatures.

Figure 9 shows the flexural strength values for both the unsubstituted FAp and the substituted $\mathrm{K}-\mathrm{OH}-\mathrm{FAp}$ samples at various sintering temperatures. The plots appeared to be of a similar trend and indicated that maximum values were in accordance with the highest density values. This was in agreement with the Duchworth-Knudsen model, indicating that the higher the relative density, the higher the strength. Thus, the highest value of $46.7 \mathrm{MPa}$ at $1050{ }^{\circ} \mathrm{C}$ was given with unsubstituted FAp sample, and then slightly decreased to $45 \mathrm{MPa}$ for $x=0.25$ at the same temperature. The obtained values were close to those reported in the literature $[35,42,43]$. For sintering temperatures exceeding $1050{ }^{\circ} \mathrm{C}$, the values significantly decreased to $\sim 30-35 \mathrm{MPa}$ at $1200^{\circ} \mathrm{C}$. An abundant porosity should be responsible for this decrement. For $\mathrm{K}-\mathrm{OH}-\mathrm{FAp}$ samples, the slight decrease in the flexural strength may be related to the abnormal grain growth and the formation of large pores.

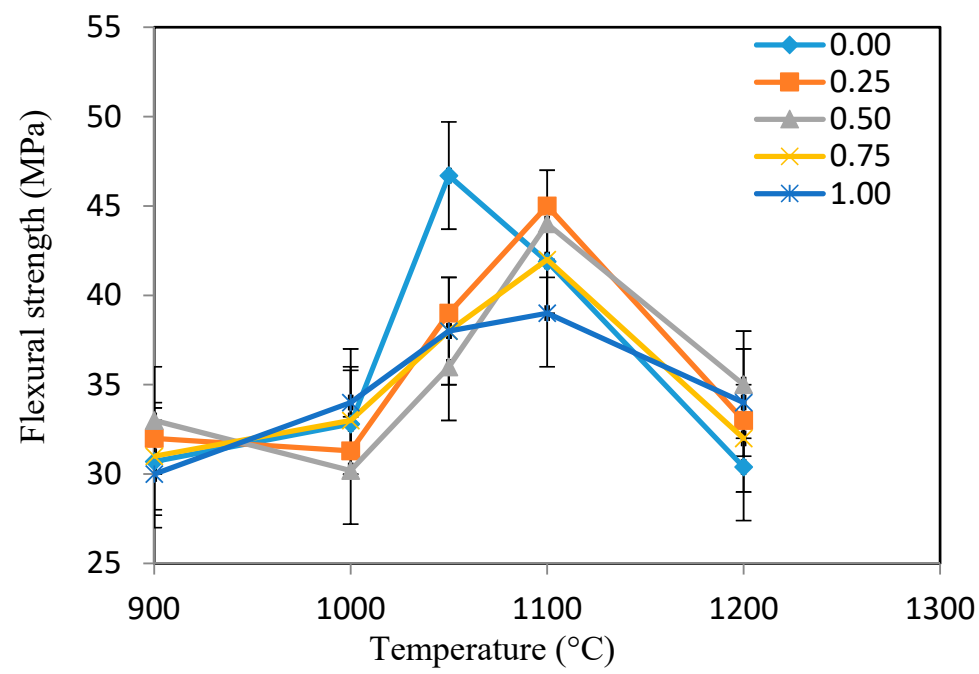

Figure 9. Numerical values of the flexural strength of $\mathrm{Ca}_{10-x} \mathrm{~K}_{x}\left(\mathrm{PO}_{4}\right)_{6} \mathrm{~F}_{(2-2 x)}(\mathrm{OH})_{x}$ for $0 \leq x \leq 1$ sintered at various temperatures.

The trend of fracture toughness shown in Figure 10 was almost similar to that of flexural strength. The toughness increased as temperature rose. The maximum value of $1.16 \mathrm{MPa} \cdot \mathrm{m}^{1 / 2}$ at $1050^{\circ} \mathrm{C}$ was obtained with FAp and then decreased as the potassium and hydroxyl were added. This decrease was marked when $x \geq 0.5$. These values, which were 
lower for substituted samples, were probably due to the presence of the secondary phase $\beta-\mathrm{Ca}_{3}\left(\mathrm{PO}_{4}\right)_{2}$ indicated by the XRD diffractograms of the Figure 5 .

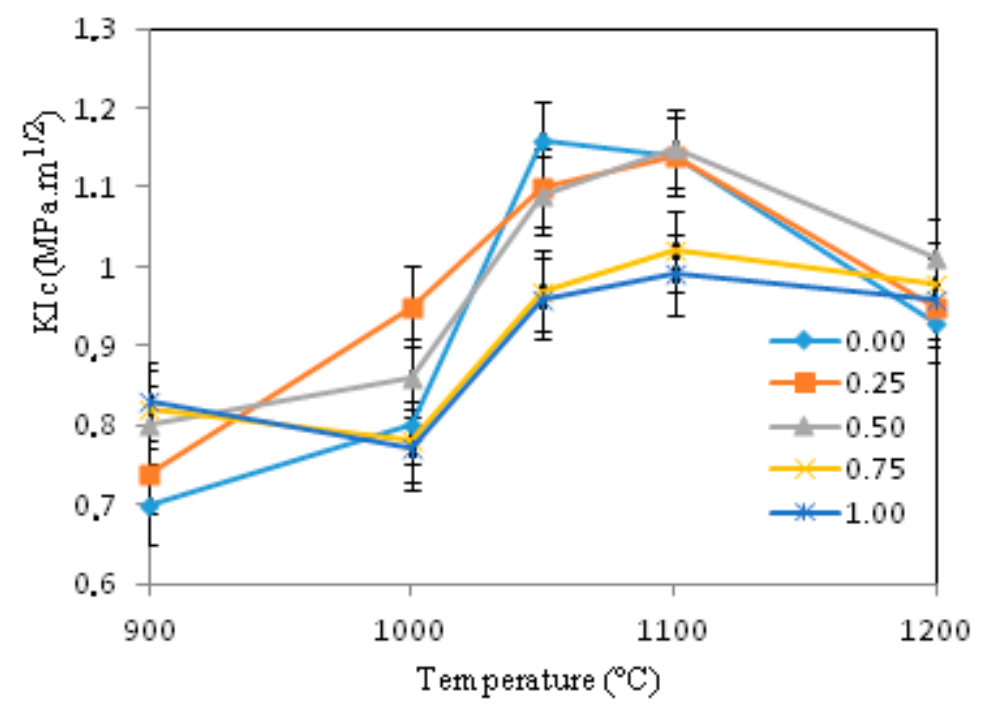

Figure 10. Numerical values of the fracture toughness of $\mathrm{Ca}_{10-x} \mathrm{~K}_{x}\left(\mathrm{PO}_{4}\right)_{6} \mathrm{~F}_{(2-2 x)} \mathrm{OH}_{x}$ for $0 \leq x \leq 1$ sintered at various temperatures.

\section{Conclusions}

The objective of the present work was to emphasize the properties of potassiumand hydroxide-doped FAp bioceramics. Ion-substituted FAp samples were prepared via the standard wet synthesis method. A slight increase in the lattice parameters and the crystal sizes was found to be coherent with the relative sizes of the doping ions. Typical of multiple substituted hydroxyflurapatites with $\mathrm{Ca} / \mathrm{P} \approx 1.66$, a heat treatment at temperatures exceeding $750{ }^{\circ} \mathrm{C}$ induced a partial decomposition of apatites, with formation of tricalcium phosphate as a result. Pressurelessly sintered K-OH-FAp samples were transformed to dense specimens; the densest one was prepared from $x=0.25$, which reached $\sim 95 \%$ of the theoretical density after $1 \mathrm{~h}$ dwelling at $1050{ }^{\circ} \mathrm{C}$. The numerical values of the mechanical data (Young's modulus, flexural strength and fracture toughness) indicated that these parameters were in good agreement with those found in the literature for similar compositions.

Author Contributions: Preparation and characterization, J.B.S., M.H. and M.G. Methodology and building, M.H., E.B.S. and S.V.D. All authors have read and agreed to the published version of the manuscript.

Funding: This research was funded by Tunisian Ministry of High Education and Scientific Research, Tunisia (TN).

Institutional Review Board Statement: Not applicable.

Informed Consent Statement: Not applicable.

Data Availability Statement: Not applicable.

Conflicts of Interest: The authors declare there are no conflict of interest to declare.

\section{References}

1. Boskey, A.L. Mineralization of bones and teeth. Elements 2007, 3, 385-391. [CrossRef]

2. Young, M.F. Bone matrix proteins: Their function, regulation, and relationship to osteoporosis. Osteoporos. Int. 2003, 14 (Suppl. 3), S35-S42. [CrossRef]

3. Currey, J.D. The structure and mechanics of bone. J. Mater. Sci. 2012, 47, 41-54. [CrossRef]

4. Rey, C.; Combes, C.; Drouet, C.; Glimcher, M.J. Bone mineral: Update on chemical composition and structure. Osteoporos. Int. 2009, 20, 1013-1021. [CrossRef] 
5. Bolger, M.W.; Romanowicz, G.E.; Kohn, D.H. Advancements in composition and structural characterization of bone to inform mechanical outcomes and modeling. Curr. Opin. Biomed. Eng. 2019, 11, 76-84. [CrossRef]

6. Jarcho, M. Calcium phosphate ceramics as hard tissue prosthetics. Clin. Orthop. Relat. Res. 1981, 157, 259-278. [CrossRef]

7. Daculsi, G.; Passuti, N.; Martin, S. Macroporous calcium phosphate ceramic for long bone surgery in humans and dogs. Clinical and histological study. J. Biomed. Mater. Res. 1990, 24, 379-396. [CrossRef]

8. Khairoun, I.; Boltong, M.G.; Driessens, F.C.M.; Planell, J.A. Some factors controlling the injectability of calcium phosphate bone cements. J. Mater. Sci. Mater. Med. 1998, 9, 425-428. [CrossRef]

9. Rey, C.; Combes, C.; Drouet, C.; Sfihi, H.; Barroug, A. Physico-chemical properties of nanocrystalline apatites: Implications for biominerals and biomaterials. Mater. Sci. Eng. C 2007, 27, 198-205. [CrossRef]

10. Dorozhkin, S.V. Calcium orthophosphates in nature, biology and medicine. Materials 2009, 2, 399-498. [CrossRef]

11. Cantaert, B.; Beniash, E.; Meldrum, F.C. The role of polyaspartic acid in the precipitation of calcium phosphate in confinement. J. Mater. Chem. B 2013, 1, 6586-6595. [CrossRef]

12. He, F.; Yang, G.; Wang, X.; Zhao, S. Effect of electrochemically deposited nanohydroxyapatite on bone bonding of sandblasted/dual acid-etched titanium implant. Int. J. Oral Maxillofac. Implant. 2009, 24, 790-799.

13. Damien, E.; Revell, P.A. Coralline hydroxyapatite bone graft substitute: A review of experimental studies and biomedical applications. Appl. Biomater. Biomech. 2004, 2, 65-73.

14. Bucholz, R.W.; Carlton, A.; Holmes, R.E. Hydroxyapatite and tricalcium phosphate bone graft substitutes. Orthop. Clin. N. Am. 1987, 18, 323-334. [CrossRef]

15. Chang, M.C.; Tanaka, J. FT-IR study for hydroxyapatite/collagen nanocomposite cross-linked by glutaraldehyde. Biomaterials 2002, 23, 4811-4818. [CrossRef]

16. Nassif, N.; Martineau, F.; Syzgantseva, O.; Gobeaux, F.; Willinger, M.; Coradin, T.; Cassaignon, S.; Azaïs, T.; Giraud-Guille, M.M. In vivo inspired conditions to synthesize biomimetic hydroxyapatite. Chem. Mater. 2010, 22, 3653-3663. [CrossRef]

17. Aoba, T. The effect of fluoride on apatite structure and growth. Crit. Rev. Oral. Biol. Med. 1997, 8, 136-153. [CrossRef]

18. Featherstone, J.D. Fluoride, remineralization and root caries. Am. J. Dent. 1994, 7, 271-274.

19. Borkowski, L.; Przekora, A.; Belcarz, A.; Palka, K.; Jozefaciuk, G.; Lubek, T.; Jojczuk, M.; Nogalski, A.; Ginalska, G. Fluorapatite ceramics for bone tissue regeneration: Synthesis, characterization and assessment of biomedical potential. Mater. Sci. Eng. C 2020, 116, 111211. [CrossRef]

20. Ten Cate, J.M.; Featherstone, J.D. Mechanistic aspects of the interactions between fluoride and dental enamel. Rev. Oral. Biol. Med. 1991, 2, 283-296. [CrossRef]

21. Jones, S.P.; Cheuk, G.C.; Georgiou, G.; Moles, D.R. Comparison of fluoridated apatites with pure hydroxyapatite as potential biomimetic alternatives to enamel for laboratory-based bond strength studies. Aust. Orthodontic J. 2009, 25, 12-18.

22. Nikčević, I.; Jokanović, V.; Mitrić, M.; Nedić, Z.; Makovec, D.; Uskoković, D. Mechanochemical synthesis of nanostructured fluorapatite/fluorhydroxyapatite and carbonated fluorapatite/fluorhydroxyapatite. J. Solid State Chem. 2004, 177, 2565-2574. [CrossRef]

23. Azami, M.; Jalilifiroozinezhad, S.; Mozafari, M.; Rabiee, M. Synthesis and solubility of calcium fluoride/hydroxy-fluorapatite nanocrystals for dental applications. Ceram. Int. 2011, 37, 2007-2014. [CrossRef]

24. Ajcharanukul, O.; Kraivaphan, P.; Wanachantararak, S.; Vongsavan, N.; Matthews, B. Effects of potassium ions on dentine sensitivity in man. Arch. Oral. Biol. 2007, 52, 632-639. [CrossRef]

25. Zhu, K.; Devine, A.; Prince, R.L. The effects of high potassium consumption on bone mineral density in a prospective cohort study of elderly postmenopausal women. Osteoporos. Int. 2009, 20, 335-340. [CrossRef] [PubMed]

26. Bushinsky, D.A.; Riordon, D.R.; Chan, J.S. Decreased potassium stimulates bone resorption. Am. J. Physiol. 1997, 272, F781-F788. [CrossRef]

27. Wiesmann, H.P.; Plate, U.; Zierold, K.; Hohling, H.J. Potassium is involved in apatite biomineralization. J. Dent. Res. 1998, 77, 1654-1657. [CrossRef]

28. Kannan, S.; Ventura, J.M.G.; Ferreira, J.M.F. Synthesis and thermal stability of potassium substituted hydroxyapatites and hydroxyapatite/ $\beta$-tricalciumphosphate mixtures. Ceram. Int. 2007, 33, 1489-1494. [CrossRef]

29. Yokota, T.; Honda, M.; Aizawa, M. Fabrication of potassium-substituted hydroxyapatite ceramics via ultrasonic spray-pyrolysis route. Phosphorus Res. Bul. 2017, 33, 35-40. [CrossRef]

30. Leroy, N.; Bres, E. Structure and substitutions in fluorapatite. Eur. Cell Mater. 2001, 2, 36-48. [CrossRef]

31. El Feki, H.; Amami, M.; Ben Salah, A.; Jemal, M. Synthesis of potassium chloroapatites, IR, X-ray and Raman studies. Phys. Stat. Sol. 2004, 1, 1985-1988. [CrossRef]

32. El Feki, H.; Naddari, T.; Savariault, J.M.; Ben Salah, A. Localisation of potassium in substituted lead hydroxyapatite: $\mathrm{Pb}_{9.30} \mathrm{~K}_{0.60}\left(\mathrm{PO}_{4}\right)_{6}(\mathrm{OH})_{1.20}$ by X-ray diffraction. Solid State Sci. 2000, 2, 725-733. [CrossRef]

33. Elliott, J.C. Structure and Chemistry of the Apatites and Other Calcium Orthophosphates, 1st ed.; Elsevier: Amsterdam, The Netherlands, 1994; Volume 18, 404p.

34. Evans, A.G.; Charles, E.A. Fracture toughness determination by indentation. J. Am. Ceram. Soc. 1976, 59, 371-372. [CrossRef]

35. Hidouri, M.; Dorozhkin, S.V.; Albeladi, N. Thermal behavior, sintering and mechanical characterization of multiple ion-substituted hydroxyapatite bioceramics. J. Inorg. Organomet. Polym. Mater. 2018, 29, 87-100. [CrossRef]

36. Okazaki, M. Heterogeneous synthesis of fluoridated hydroxyapatites. Biomaterials 1992, 13, 749-754. [CrossRef] 
37. Nsar, S.; Hassine, A.; Bouzouita, K. Sintering and mechanical properties of magnesium and fluorine co-substituted hydroxyapatites. J. Biomater. Nanobiotechnol. 2013, 4, 1-11. [CrossRef]

38. Hata, M.; Okada, K.; Iwai, S. Cadmium hydroxyapatite. Acta Cryst. B 1978, 34, 3062-3064. [CrossRef]

39. Šupová, M. Substituted hydroxyapatites for biomedical applications: A review. Ceram. Int. 2015, 41, 9203-9231. [CrossRef]

40. Hidouri, M.; Dorozhkin, S.V. Structure and thermal stability of sodium and carbonate-co-substituted strontium hydroxyfluorapatites. N. J. Chem. 2018, 42, 8469-8477. [CrossRef]

41. Xu, J.L.; Khor, K.A. Chemical analysis of silica doped hydroxyapatite biomaterials consolidated by a spark plasma sintering method. Inorg. Biochem. 2007, 101, 187-195. [CrossRef]

42. Kingery, W.D.; Bowen, H.K.; Uhlmann, D.R. Introduction to Ceramics; Wiley: New York, NY, USA, 1976; 1056p.

43. Martin, R.I.; Brown, P.W. Mechanical properties of hydroxyapatite formed at physiological temperature. J. Mater. Sci. Mater. Med. 1995, 6, 138-143. [CrossRef] 